\title{
The morphological characters of Mothocya taurica (Czerniavsky, 1868) and Emetha audouini (H. Milne Edwards, 1840) from Turkey
}

\author{
AHMET ÖKTENER ${ }^{1, \boldsymbol{\vartheta}}$, ALI ALAŞ ${ }^{2}$, DILEK TÜRKER ${ }^{3}$ \\ ${ }^{1}$ Deparment of Fisheries, Sheep Research Station. Çanakkele Street 7km.,10200, Bandırma, Balıkesir, Turkey. Tel.: +90-266-7380080, `email: \\ ahmetoktener@yahoo.com \\ ${ }^{2}$ Department of Biology, Faculty of Education, Necmettin Erbakan University. B Block, 42090, Meram, Konya, Turkey \\ ${ }^{3}$ Department of Biology, Faculty of Science, Balikesir University. Cagis Campus, 10300, Balikesir, Turkey
}

Manuscript received: 30 May 2017. Revision accepted: 27 June 2017

\begin{abstract}
A, Alaş A, Türker D. 2017. The morphological characters of Mothocya taurica (Czerniavsky, 1868) and Emetha audouini (H. Milne Edwards, 1840) from Turkey. Bonorowo Wetlands 7: 55-64. This paper aims to present morphological characters of two species, Mothocya taurica (Czerniavsky, 1868) and Emetha audouini (H. Milne Edwards, 1840) from Turkey. Although Mothocya taurica with different synonymies were described by several researchers, Bruce (1986) indicated the necessity of redescription of Mothocya taurica. Pleopods 1 to 5 having medial peduncle margin with 4 hooks of Emetha audouini is found for the first time in this study as distinct from other studies. Also, the host preferences of these parasites are given.
\end{abstract}

Keywords: Cymothoidae, Emetha, Isopoda, morphology, Mothocya, Turkey

\section{INTRODUCTION}

Cymothoids are ectoparasitic isopods on the body, fins, or inside the buccal or the branchial cavities of numerous freshwater and marine fishes. They are protandrous hermaphrodite (Bariche and Trilles 2005). Although the Cymothoidae family is famously known, there are some deficiencies from the taxonomic point of view. According to some researchers, studies concerned with molecular and morphological are needed on this family (Poore and Bruce 2012; Martin et al. 2013; Hadfield et al. 2016).

Thirty-one species in the Mothocya genus and two in the Emetha genus were listed by The World Register of Marine Species (Hadfield et al., 2017; Schotte 2007). Three species (Mothocya epimerica, Mothocya taurica, Mothocya belonae) of Mothocya and one species (Emetha audouini) of Emetha are reported from Turkish waters, but these studies include limited information about the morphology of mouth-parts (Öktener and Trilles 2004; Kırkım 1998). Mothocya taurica was reported from the Black Sea, the Mediterranean Sea (Trilles 1994; Bruce 1986; Kononenko 1988; Ramdane et al. 2006). Bruce (1986) pointed out a needed evaluation of the status of this species.

The morphological characters are given in the study obtain a possibility to compare the other countries' findings next time. Although it could not use electron microscopy, the DNA barcoding and molecular identification methods are reliable and expensive in this study. It aims to present the morphological characters, especially including mouthparts of Mothocya taurica and Emetha audouini from Turkey.

\section{MATERIALS AND METHODS}

Eighty-three Alosa sp. (Pisces; Clupeidae) and 38 picarel Spicara maena (Linnaeus, 1758) (Pisces; Centracanthidae), 56 Sardinella auritaValenciennes, 1847 (Clupeidae), 170 Engraulis encrasicolus (Linnaeus, 1758) (Engraulidae) were collected with the local fishing gears in the Sea of Marmara in 2014. The collected parasites were fixed in $70 \%$ ethanol. Mouthparts and pleopods were dissected using a Wild M5 stereo microscope. The dissected parts were mounted on slides in a glycerin-gelatine mounting medium. The pleopods of isopods were stained with methylene blue. The appendages were drawn with the aid of a camera lucida (Olympus BH-DA). The photos were taken with Canon EOS 1100D camera attached to the microscope. The measurements were taken in millimeters $(\mathrm{mm})$ with a micrometric program (Pro-way). The scientific names synonyms of parasite and host were checked with the WoRMS Editorial Board (2017). According to Froese and Pauly (2017), the host's feeding habits and habitat characteristics were prepared. Mothocya taurica (MNHNIU-2013-18751) and Emetha audouini (MNHN-IU-201716) was deposited in the collections of the Musée National d'Histoire Naturelle (MNHN), Paris, France.

\section{RESULTS AND DISCUSSION}

\author{
Mothocya taurica (Czerniavsky, 1868) (Figure 1-6) \\ Synonyms: \\ Cymothoa oestrum Rathke, 1837: 394 \\ Cymothoa punctata Uljanin, 1872: 113-114.-Popov,
} 1933: 193,196-198.-Markewitsch, 1934: 224,225, pl.XLV (fig.10-11).-Nikolaeva, 1963: 1-46 
Lironeca pontica Borcea, 1933a: 128.— Borcea, 1933b: 481-502, figs 1-9, pls 2-4.

Livoneca punctata Vasiliu and Carausu, 1948: 180-184, pl.II (fig.1-12),pl.III (fig.13-38d).-Carausu, 1959: 349351,pl.I (fig.A-B)

Lironeca punctata Trilles, 1976a: 782-783, pl.I. fig.6.Dollfus and Trilles, 1976: 828

Lironeca taurica Kussakin, 1979: 295, figs. 160, 161.

Livoneca taurica Uljanin, 1871: 113.-Uljanin, 1872: 113

Host: Alosa sp. (the shad); Locality: Bandirma Bay; Total parasite: 5; Dissected parasite: 3 .

All parasites were firmly attached to the gill cavity of the host. The prevalence means the intensity of parasites were $6 \%, 1$ respectively.

Description-female: Body length varies from 15 to 19 $\mathrm{mm}$. Body slightly twisted to one side, about 2 times as long as wide. Pereon widest at pereonite 4 , most narrow at pereonite 1. Coxal plates are visible in dorsal view, with round posterior margins. Length of coxae greater than width. Pereonite 1 longest, length of pereonites decreasing step by step from 3 to 7 ; pereonite 7 shortest. The width of the head is about 2 times the head length. Pleotelson wider than length, posterior margin evenly rounded, about 1.6 wider than long. All pleonites visible, the first pleonite distinctly narrow, 2-5. pleonites slightly wider. Pleon 1 largely and pleon 2 partially concealed by pereonite 7 . Antennula and antenna are composed of eight articles. Mandible palp third article distinctly shorter than others. Maxillula with four terminal spines, one long and three short spines. Maxilla medial lobe with 2 spines, lateral lobe with 2 spines. Maxilliped article 3 with five hooked spines. Pereopods 5-7 are slightly larger than pereopod 1-4, all without spines. Pleopods 1 to 5 has a medial peduncle margin with 4 hooks. Pleopods 3 to 5 endopods with large proximomedial lobes. Uropod rami not extending beyond pleotelson; endopod slightly longer than exopod.

Distribution: Black Sea, Mediterranean Sea, Aegean Sea (Bruce 1986; Kononenko 1988; Trilles 1994; Ramdane et al. 2006; Schotte 2008a; Ramdane et al. 2009;).

Hosts: Alosa immaculata (Borcea 1933a; Borcea 1933b; Vasiliu and Carausu 1948; Muradian 1972; Kussakin 1979; Trilles 1976; Bruce 1986; Trilles 1994; Öktener and Trilles 2004; Olguner 2008; Öktener et al. 2010); Alosa fallax (Dollfus and Trilles 1976); Atherina hepsetus and Gobius sp (Markewitsch 1934); Alosa tanaica, Pomatomus saltatrix (Borcea 1933a); Engraulis encrasicolus, Sprattus sprattus, Trachurus mediterraneus (Nikolaeva 1963); Helicolenus dactylopterus, Trisopterus minutus (Öktener et al. 2009); Sardina pilchardus (Borcea 1933a; Markewitsch 1934; Vasiliu and Carausu 1948); Scorpaena porcus (Markewitsch 1934; Josipa et al. 2007).

The host's parasitism with Mothocya taurica has been examined according to family characteristics $37 \%$ of 13 hosts belong to Clupeidae, and 63\% to Carangidae, Gadidae, Scorpaenidae, Pomatomidae, Sebastidae, Gobiidae, Engraulidae, and Atherinidae. The host's parasitism with Mothocya taurica was examined according to habitat selections; $54 \%$ of 13 host fish species are pelagic-neritic; $15 \%$ pelagic-oceanic; $15 \%$ demersal; $8 \%$ benthopelagic, and
$8 \%$ bathydemersal. According to feeding habits, the host's parasitism with Mothocya taurica; all hosts are carnivorous.

Clupeidae fishes are hosts of Mothocya taurica. This parasite selects carnivorous and pelagic fishes as hosts for habitat and feeding habits. This study examined Alosa sp. is a carnivorous and pelagic fish. It is fit as preferring host for Mothocya taurica. Although it should indicate references to this statement that Mothocya taurica is also reported from Engraulis encrasicolus and Sardinella aurita, it was not found in these fishes.

Remarks: The antennula and the antenna with 8 articles found in this study agree with the descriptions of Borcea (1933b); Vasiliu and Carausu (1948); Kussakin (1979); Bruce (1986); Öktener et al. (2010, re-examined). The maxillula with four terminal spines found in this study is compatible with Kussakin (1979), Vasiliu and Carausu (1948), and Öktener et al. (2010). The medial lobe and lateral lobe with 2 spines of maxilla found in this study are compatible with the findings indicated by Kussakin (1979) and Öktener et al. (2010), while the medial lobe with 1 spine and the lateral lobe with 2 spines mentioned by Vasiliu and Carausu (1948).

The third article without setae on the lateral margin of the mandible palp found in this study is compatible with the descriptions of Kussakin (1979) and Öktener et al. (2010), excepting for Vasiliu and Carausu (1948) findings. Five spines on article 3 of the maxilliped of ovigerous female were observed in this study, while 4 spines on an article of ovigerous female maxilliped were described by Kussakin (1979); 4 spines on an article of female maxilliped by Vasiliu and Carausu (1948), and 5 spines on an article of ovigerous female maxilliped by Öktener et al. (2010).

There are limited studies about the morphology of Mothocya taurica (Borcea 1933b; Vasiliu and Carausu 1948; Kussakin 1979; Bruce 1986; Öktener et al. 2010). The findings of the structures of mouthparts, pereopod, and pleopod in this study agree with the previous literature. In appearance, Mothocya taurica is very similar to $M$. belonae. It can be distinguished by having slightly wider coxae, a rounder pleotelson, and pleopods 3 to 5 endopods with much larger proximomedial lobes as well as a distolateral extension, according to Bruce (1986).

\section{Emetha audouini (H. Milne Edwards, 1840) (Figure 9-14) Synonyms:}

Cymothoa audouini Milne-Edwards, 1840: 274-275.Heller, 1866: 738-739.-Stalio, 1877: 237.-Stossich, 1880: 45.-Gerstaecker, 1901: 255-257

Cymothoa nigropunctata Hope, 1851: 33

Cymothoa audouinii: Hope, 1851: 33

Emetha audouinii Schioedte and Meinert, 1883: 317321, tab.XI, fig.14-18.-Dudich, 1931: 18.-Montalenti, 1941: 337-394.-Montalenti, 1948: 27-36,tav.I (fig.1-8).Amar, 1951: 530.-Euzet and Trilles, 1961: 190-191.Trilles, 1962: 103-106.-Trilles, 1964: 107-108.-Trilles, 1968: 20-36, plI-IV,phot.2-5.-Thampy and John, 1974: 580, 582.-Quignard and Zaouali, 1980: 357.-Brusca, 1981: 127.- Sartor, 1986: 1-12.-Sartor, 1987: 49.Wagele, 1987: 1-398. 

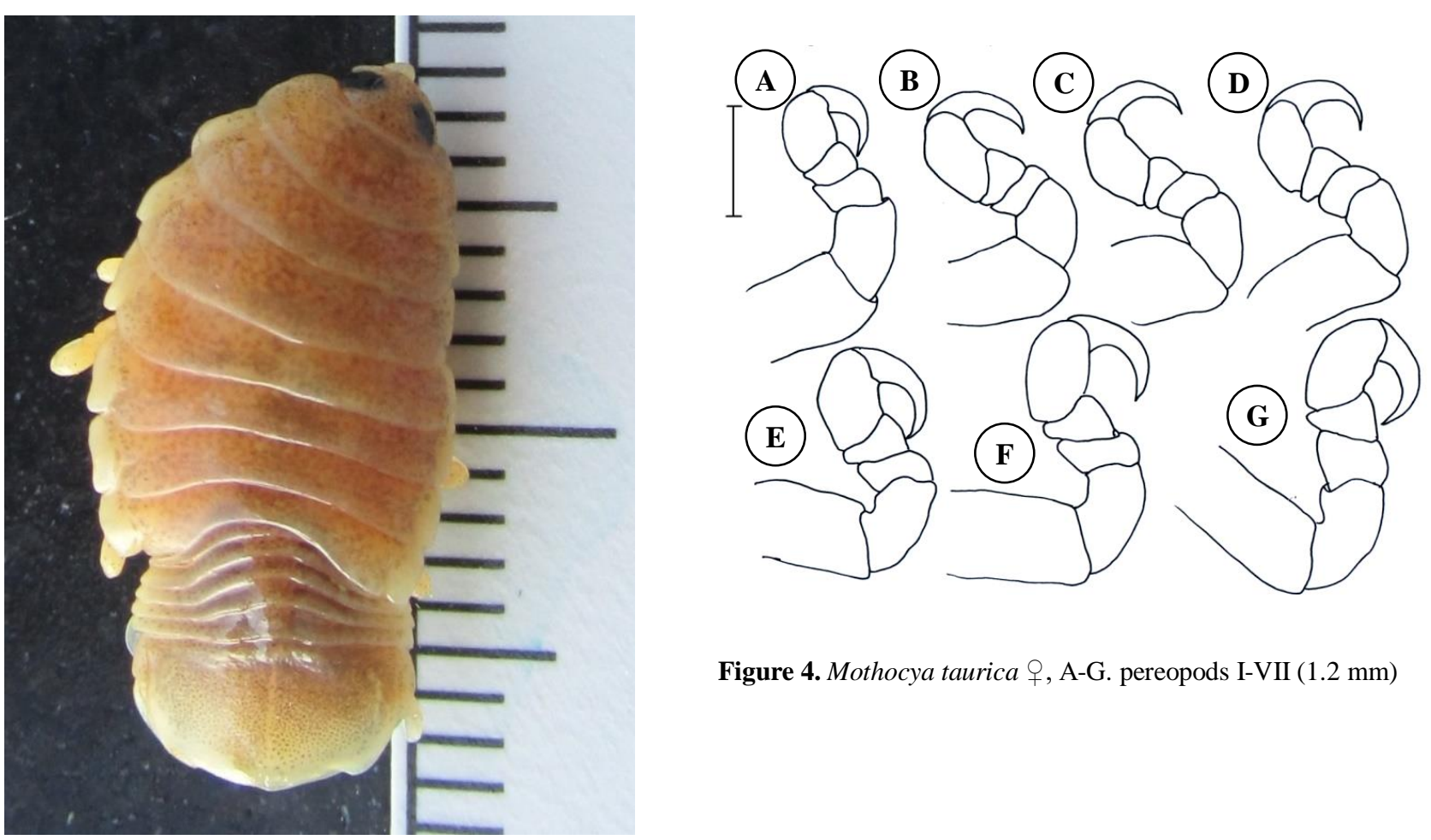

Figure 4. Mothocya taurica , A-G. pereopods I-VII (1.2 mm)

Figure 1. Mothocya taurica우
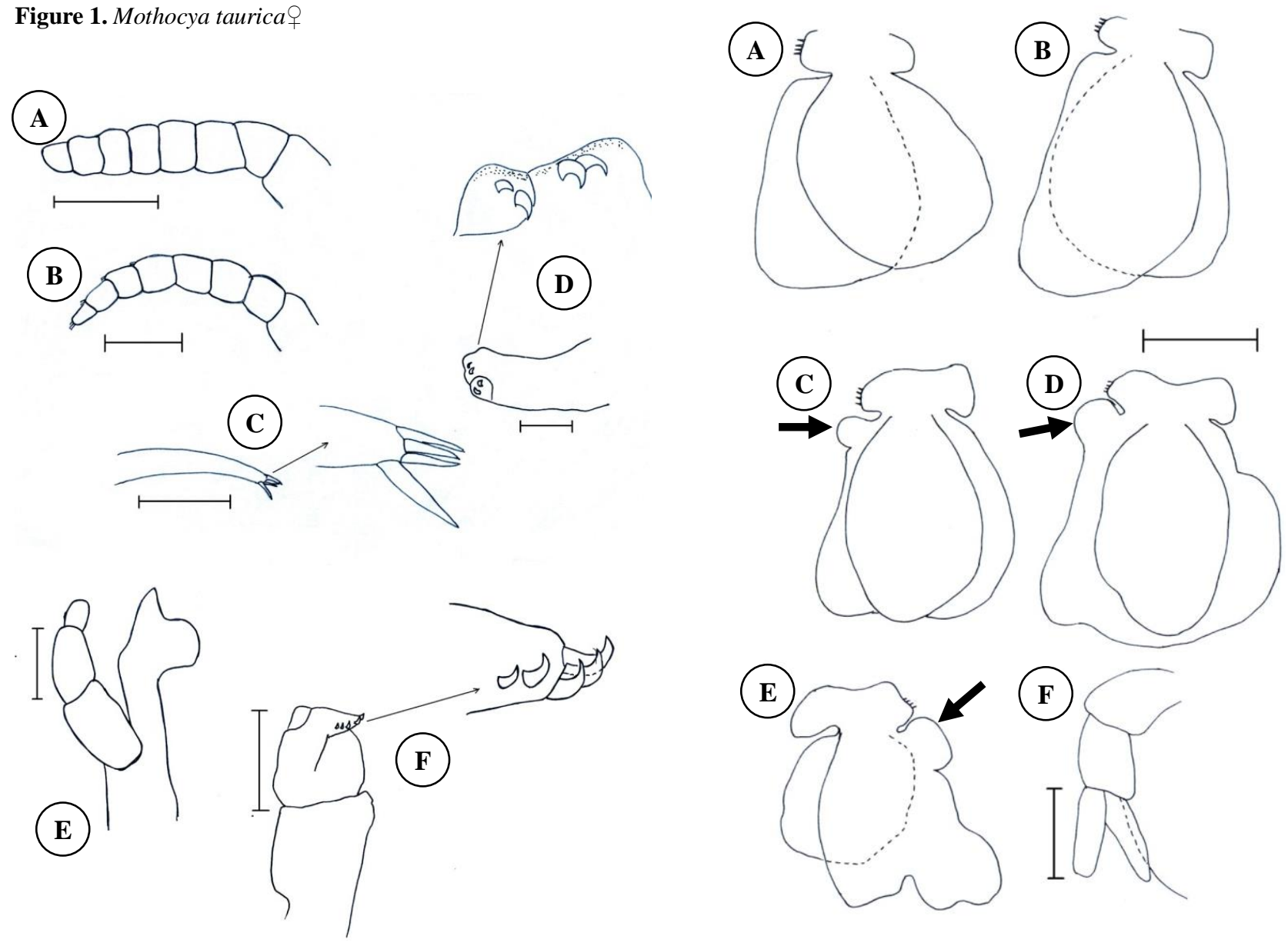

Figure 3. Mothocya taurica ${ }^{\circ}$, A. antennula $(0.25 \mathrm{~mm}), \mathrm{B}$. antenna $(0.27 \mathrm{~mm})$, C. maxillula $(0.40 \mathrm{~mm})$, D. maxilla $(0.26$ $\mathrm{mm})$, E. mandible $(0.35 \mathrm{~mm})$, F. maxilliped $(0.47 \mathrm{~mm})$

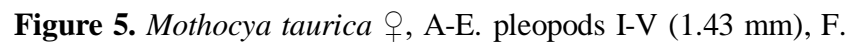
uropod $(1.33 \mathrm{~mm})$. 


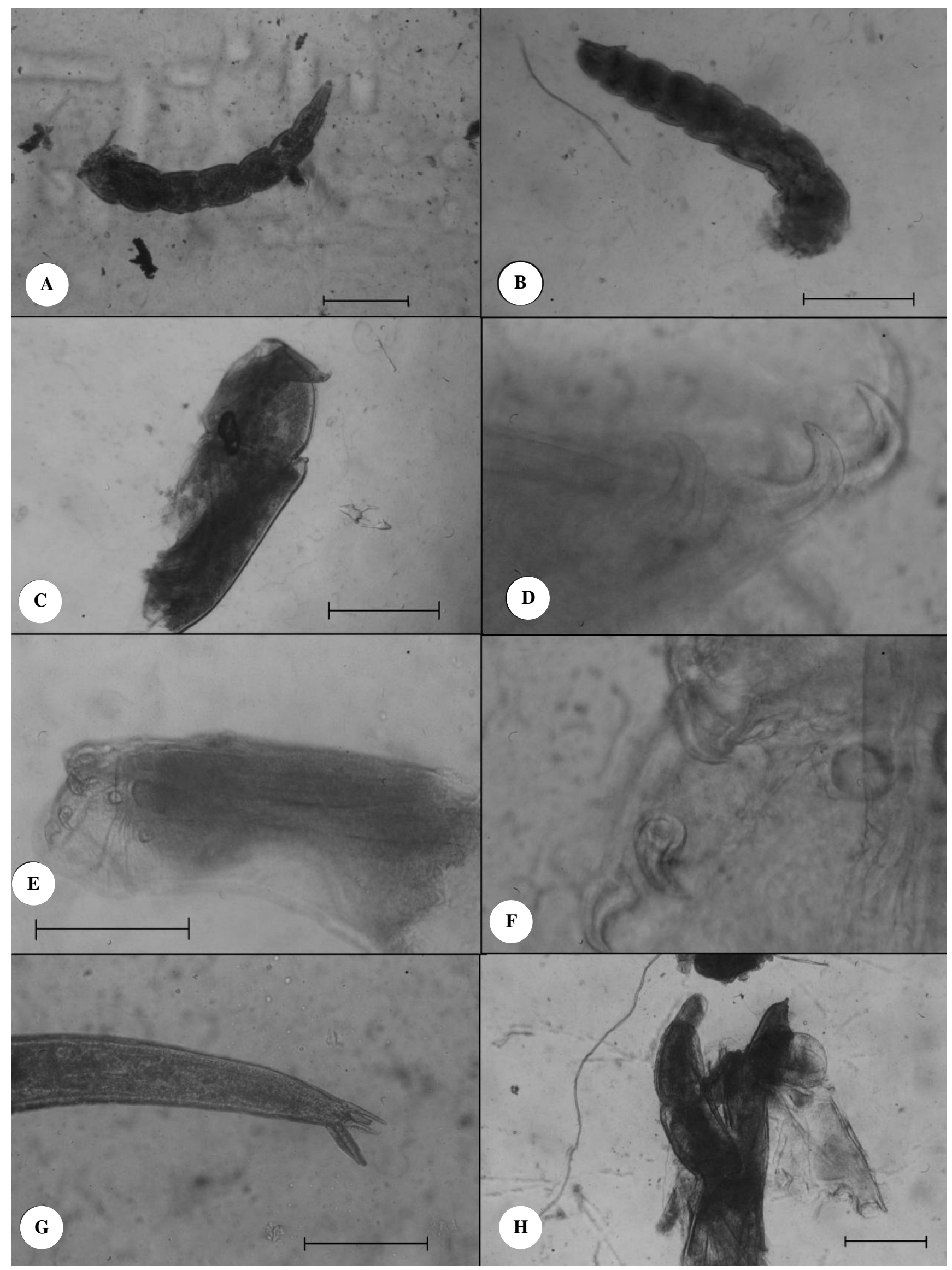

Figure 2. Mothocya taurica , A. antenna $(0.27 \mathrm{~mm})$, B. antennula $(0.25 \mathrm{~mm})$, C. maxilliped $(0.47 \mathrm{~mm})$, D. spines on maxilliped $(2$ $\mathrm{mm})$, E. maxilla $(0.26 \mathrm{~mm})$, F. spines on maxilla, G. maxillula $(0.10 \mathrm{~mm}), \mathrm{H}$. mandible $(0.14 \mathrm{~mm})$ 


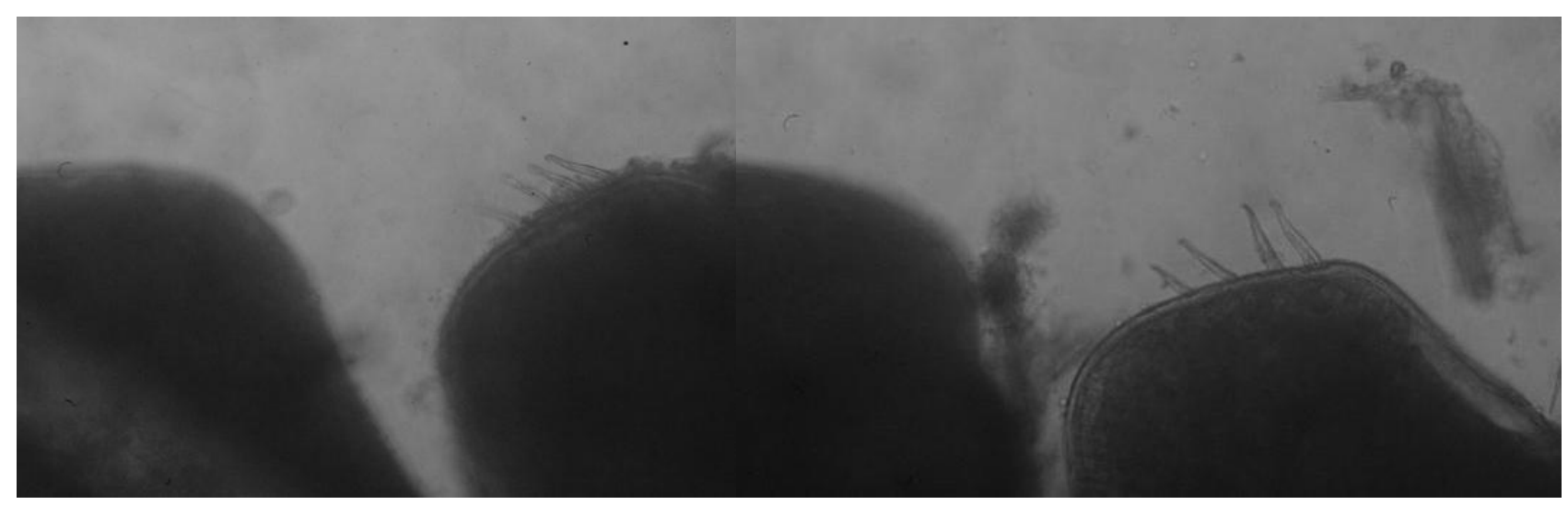

Figure 6. Four hooks on medial peduncle margin of pleopods (Mothocya taurica 9 )

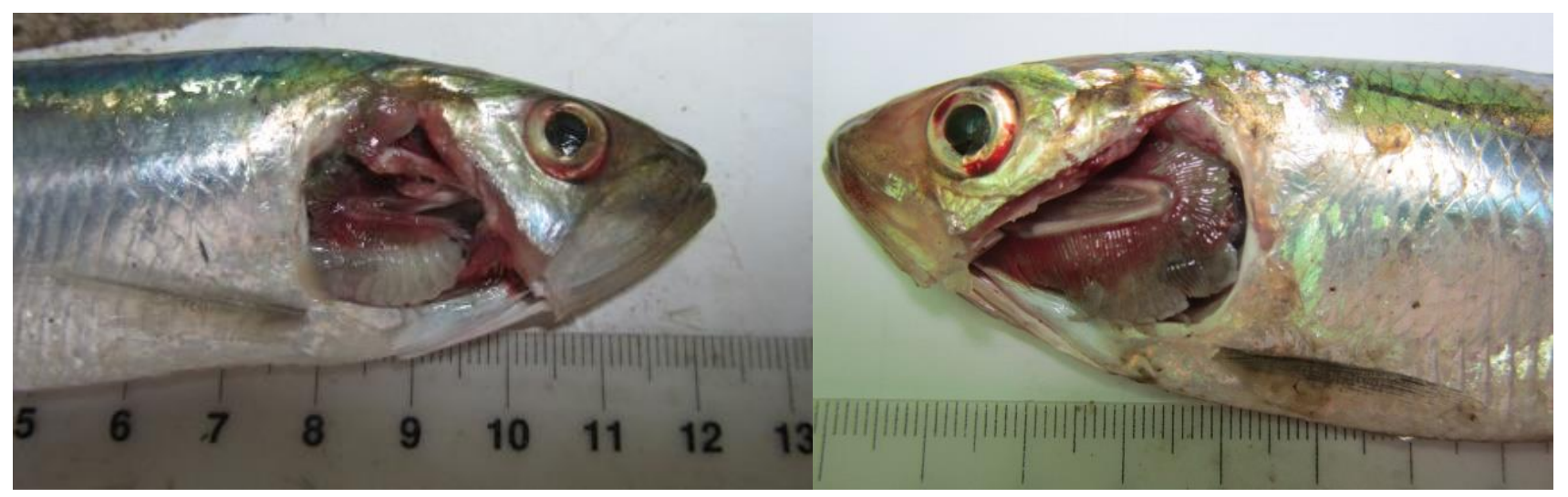

Figure 7. Mothocya taurica on the right and left gill chamber of fish

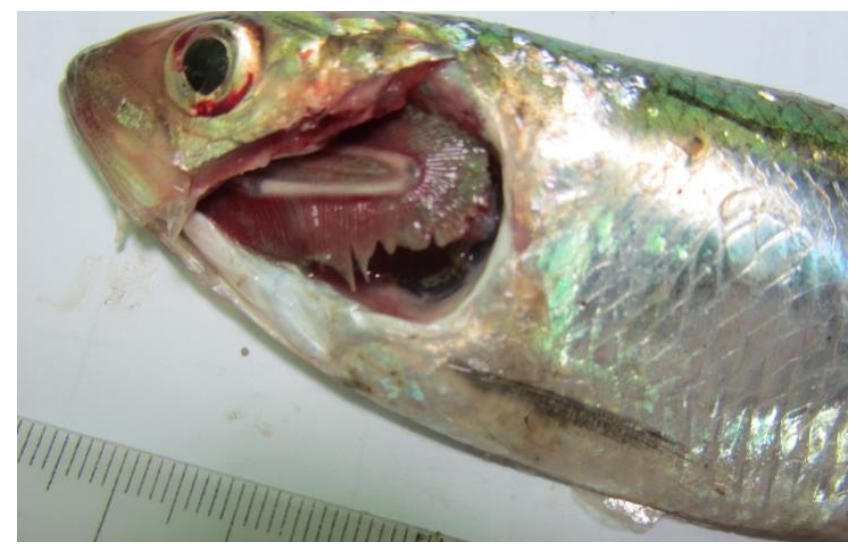

Figure 8. Atrophy on the gill filaments of fish parasitized by Mothocya taurica

Emetha audouini Carus, 1885: 442.-QuintardDorques, 1966: 10.—Berner, 1969: 93-95.—Trilles, 1972a: 1192-1196, fig.1-45, pl (1-3).-Trilles, 1972b: 12321233.-Trilles, 1972c: 1269-1277, fig.1-13.-Trilles,
1977: 8.- Romestand and Trilles, 1977: 92-95, fig.1-2.Radujkovic, 1982: 155-161.-Radujkovic et al, 1984: 161181.- Trilles et al. 1989: 279-306, fig.7

Emetha adriatica Bovallius, 1885: 17-20, pl.IV (fig. 3440)

Ceratothoa salparum Gourret, 1891: 18-19, tav.I (fig. 19), tav. XI (figs.7-13)

Host: Spicara maena (Linnaeus, 1758) (Blotched picarel); Locality: Bandırma Bay; Total parasite: 8; Dissected parasite: 6 .

All parasites were firmly attached to the mouth cavity of the host. The prevalence means the intensity of parasites was $21 \%, 1$ respectively.

Description-female: Body length varies from 18 to 22 $\mathrm{mm}$. The body expands from anterior to posterior, later narrow. The body is about 2.5-3 times as long as wide. The width of pereonites increases from 1 to 5 , after that decreasing. Pereonite 5 widest, pereonite 7 narrowest. 3-7 coxal plates visible in dorsal view. 3-5 pereonites are approximate of equal length, pereonite 7 shortest. The eyes are small, concealed by antennula and antenna. Pleotelson wider than large, posterior margin rounded. All pleonites visible, first pleonite narrowest. 2-5 pleonites wider than 
the first one. All pleonites are of equal length. Antennula is extending to behind the eye, composed of seven articles. Antenna extending to the middle of 1 pereon. Pereon, with eight articles. Mandible palp third article distinctly shorter than others, without setae. Maxillula with four terminal spines, one long and three short spines. Maxilla medial lobe with 2 spines, lateral lobe with 3-4 spines. Maxilliped article 6 with five hooked spines in ovigerous and nonovigerous females. Pereopods 1-3 are slightly smaller than 4-7, all without spines. The expansion on the upper and lower parts of 5-7 pereopod is distinct from 1-4 pereopods. Pleopods gradually decrease in length. Pleopods 1 to 5 has a medial peduncle margin with 4 hooks. Uropod rami extend to the posterior margin of the pleotelson. Exopod is slightly longer than endopod.

Distribution: The Mediterranean Sea, Adriatic (Trilles 1994; Schotte 2008b).

Hosts: Boops boops (Montalenti 1948; Kırkım 1998); Spicara smaris (Montalenti 1948; Berner 1969; Papoutsoglou 1976; Trilles 1977; Trilles et al. 1989; Ramdane et al. 2009; Radujkovic et al. 1984; Kırkım 1998); Spicara maena (Montalenti 1948; Berner 1969; Romestand et al. 1976; Öktener and Trilles 2004); Sarpa salpa (Montalenti 1948); Centracanthus cirrus (Schioedte and Meinert 1883); Pagellus acarne, Raja clavata (Trilles et al. 1989); Scomber scombrus (Balcells 1954); Dicentrarchus labrax (Papapanagiotou et al. 1999); Clupea sp (Trilles 1977).

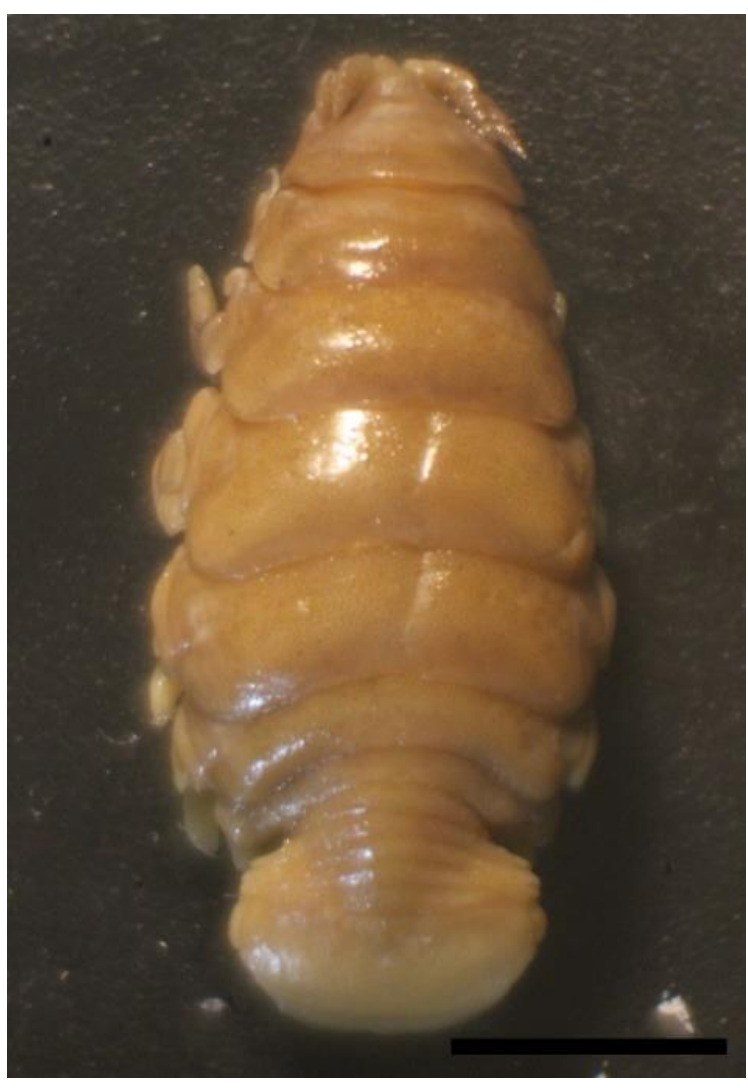

Figure 9. 1Emetha audouini +

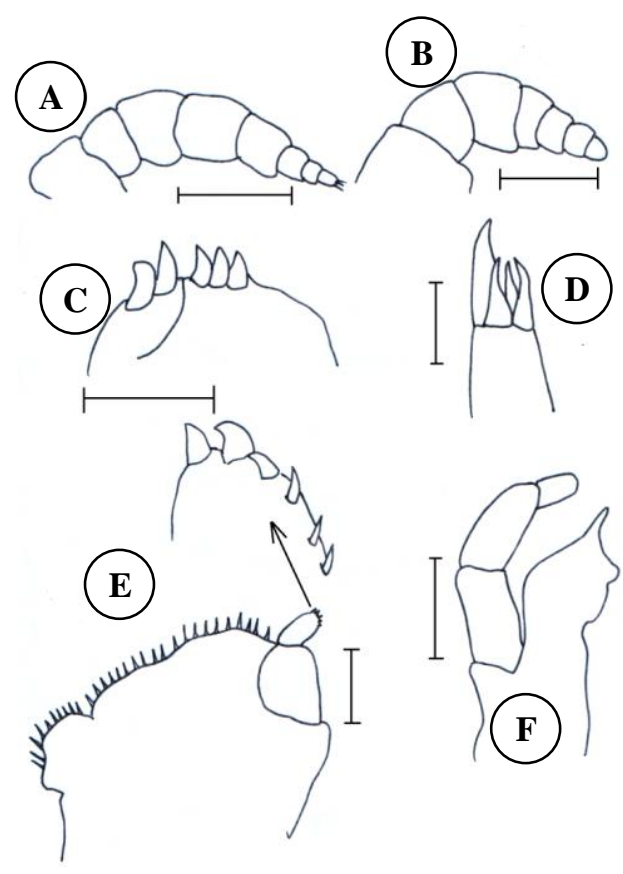

Figure 11. Emetha audouini o, A. antenna $(0.68 \mathrm{~mm})$, B. antennula $(0.74 \mathrm{~mm})$, C. maxilla $(0.21 \mathrm{~mm})$, D. maxillula $(0.11$ $\mathrm{mm})$, E. maxilliped (0.24 mm), F. mandible $(0.34 \mathrm{~mm})$

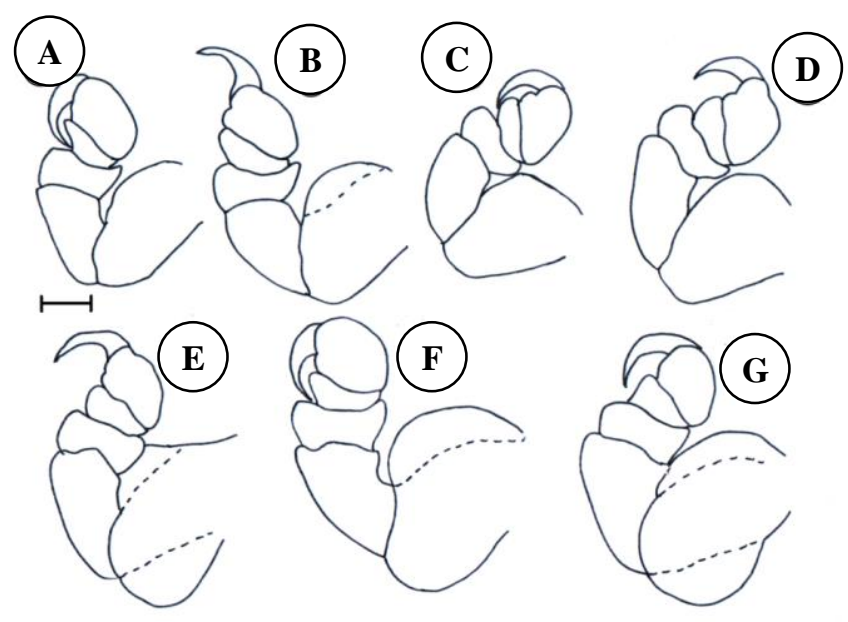

Figure 12. Emetha audouini $\odot$, A-G. pereopods I-VII $(0.56 \mathrm{~mm})$

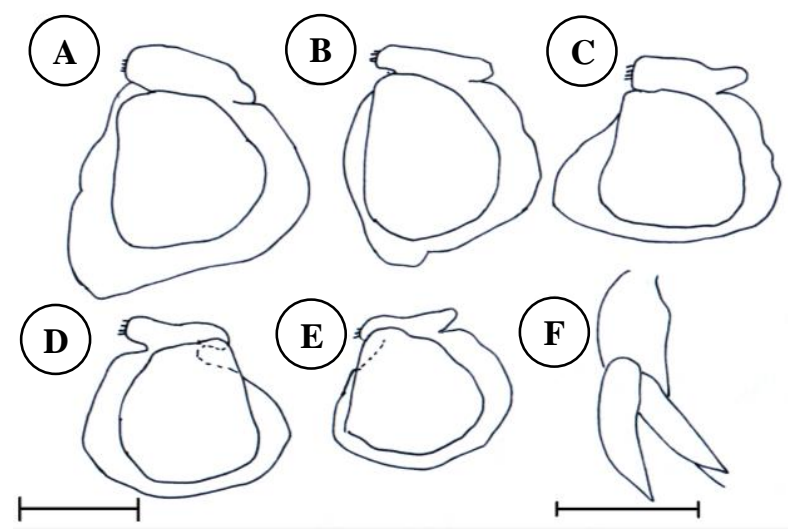

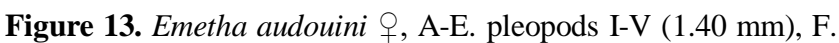
Uropod $(0.96 \mathrm{~mm})$ 


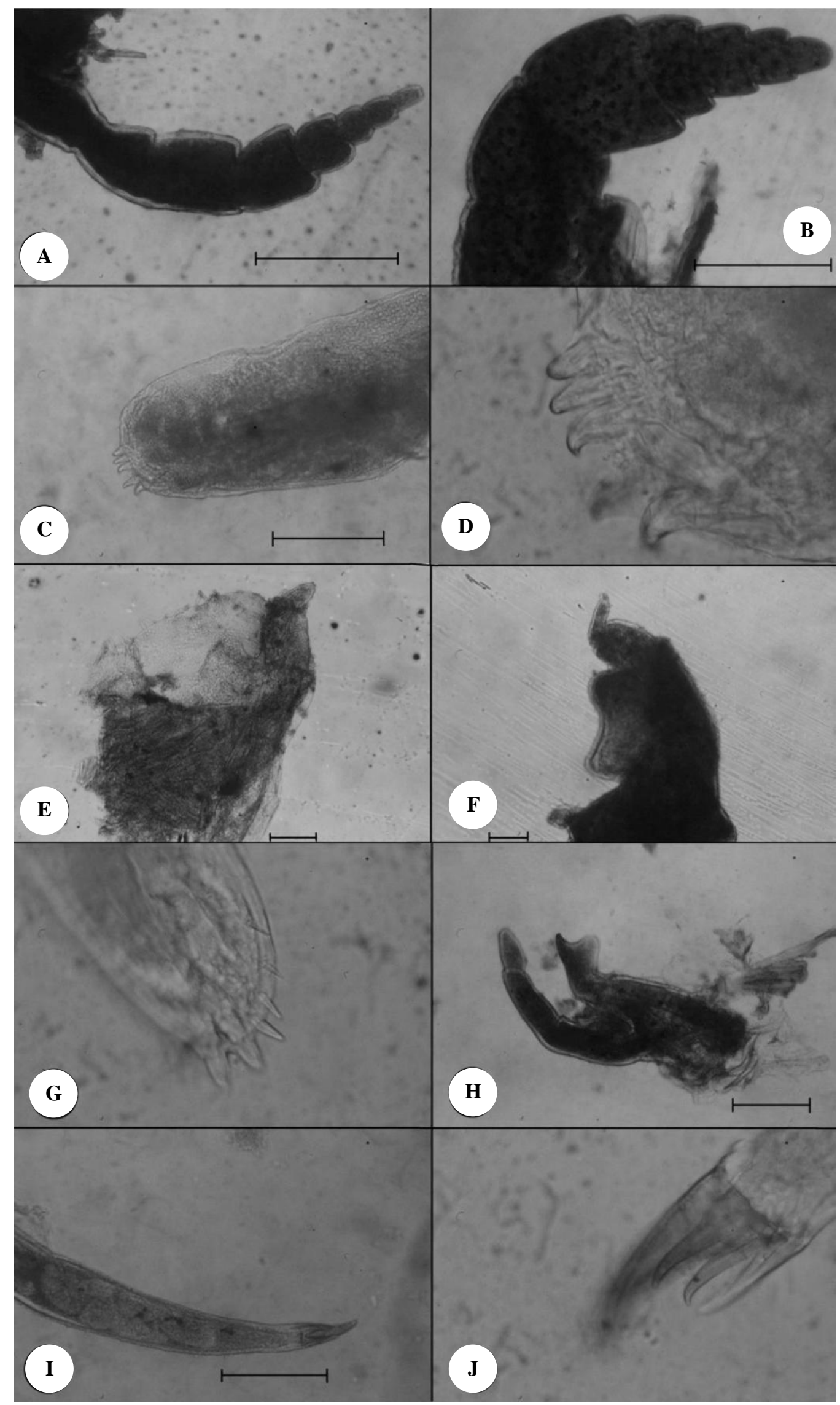

Figure 10. Emetha audouini + , A. antenna $(0.68 \mathrm{~mm})$, B. antennula $(0.37 \mathrm{~mm})$, C. maxilla $(0.24 \mathrm{~mm})$, D. distal of maxilla, E. maxilliped of non-ovigerous female $(0.17 \mathrm{~mm})$, F. maxilliped of ovigerous female $(0.21 \mathrm{~mm})$, G. distal of maxilliped, H. mandible $(0.35$ $\mathrm{mm})$, I. maxillula $(0.30 \mathrm{~mm})$, J. distal of maxillula. 


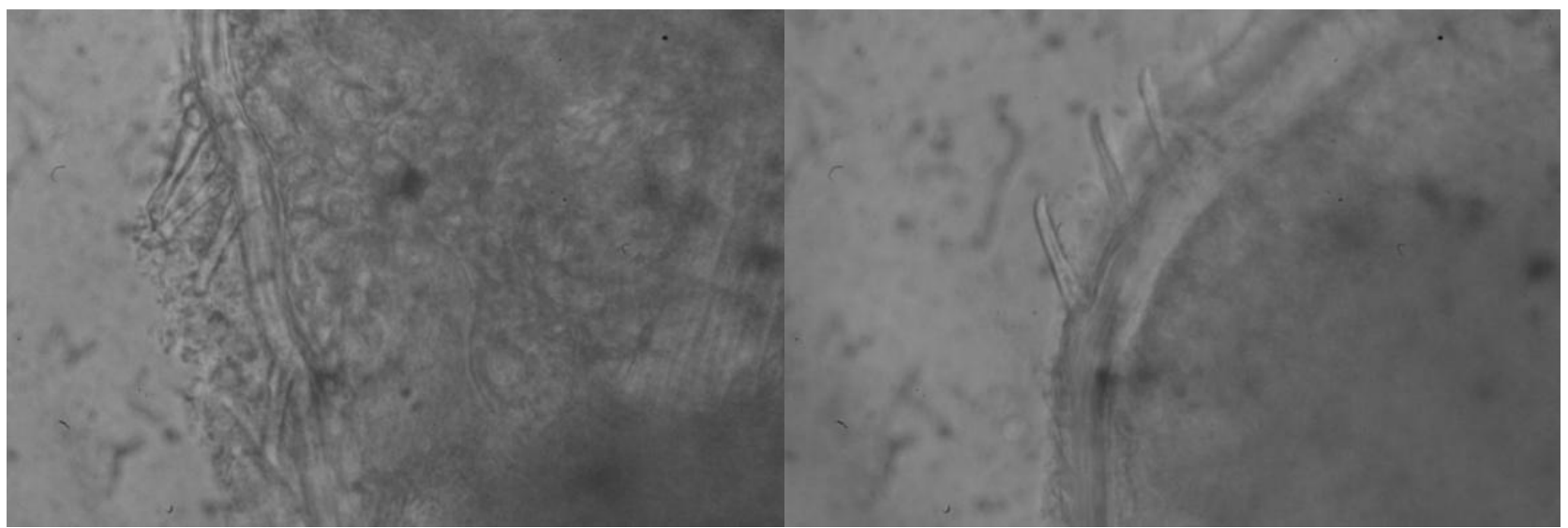

Figure 14. Four hooks on medial peduncle margin of pleopods (Emetha audouini $_{+}$)

The host's parasitism with Emetha audouini was examined according to the family characteristics; $30 \%$ of 10 host species belong to Sparidae; $30 \%$ to Centracanthidae; $40 \%$ to Rajidae, Scombridae, Moronidae, and Clupeidae. According to habitat selections, the host's parasitism with Emetha audouini was examined; $30 \%$ of 10 host fish species are benthopelagic; 30\% demersal; 30\% pelagic-neritic; $10 \%$ pelagic-oceanic. The host's parasitism with Mothocya taurica was examined according to feeding habits; $60 \%$ of the 10 host fish species are omnivorous; $40 \%$ carnivorous.

Fish of the Centracanthidae family are the preferred hosts for Emetha audouini, which mainly select omnivorous and benthopelagic fishes.

Remarks: The antennula with 7 articles and antenna with 8 articles are were observed in this study, while antennula and antenna with 7 articles are indicated by Montalenti (1948); antennula with 7 articles and antenna with 9 articles by Trilles (1972) and Kurkım (1988); antennula and antenna with 8 articles by Schioedte ve Meinert (1883). The maxillula with four terminal spines found in this study is compatible with Trilles $(1968,1972)$ and Montalenti (1948)'s findings. The medial lobe with 4-7 spines and lateral lobe with 6-12 spines of the maxilla is found in this study, while the medial lobe without spines and the lateral lobe with 4 spines were found by Montalenti (1948); medial lobe with 1 spine and lateral lobe with 3 spines by Trilles $(1968,1972)$. The third article with setae on the lateral margin of the mandible palp found in this study is compatible with Trilles's (1968, 1972) and Montalenti's (1948) are finding. This study found six spines on article 3 of maxilliped of ovigerous and nonovigerous females, while 6 spines on an article of only ovigerous female maxilliped were described by Trilles (1968). The observed expansions based on pereopod 7 distinct from pereopods 1-4 are compatible with Trilles (1968, 1972) and Montalenti (1948) findings. The pleopods 1 to 5 having peduncle medial margin with 4 hooks are found for the first time as distinct from the previous studies.

\section{REFERENCES}

Amar R. 1951. Isopodes marins de Banyuls. Vie et Milieu 2 (4): 529-530. Balcells E. 1953. Sur des isopodes, parasites de poissons. Vie et Milieu 4 (3): 547-552.

Bariche M, Trilles JP. 2005. Preliminary check-list of Cymothoids (Crustacea, Isopoda) from Lebanon, parasitingon marine fishes. Zool Middle East 34 (1): 5-12. DOI: 10.1080/09397140.2005.10638082.

Berner L. 1969. Les principaux Cymothoides (Crustaces Isopodes) du Golfe de Marseille. Bulletin du Museum d'Histoire Naturelle de Marseille 29: 93-95.

Borcea I. 1933a. Livoneca pontica nov. sp., copepode parasite des Aloses et Sardines de la Mer Noire. Bulletin du Muséum National d' Histoire naturelle de Paris 2: 128-129.

Borcea I. 1933b. Livoneca pontica nov. sp., Cymothoide parasite des Aloses et Sardines de la Mer Noire. Annales Scientifiques de 1' Université de Jassy 17: 481-502.

Bovallius C. 1885. New or imperfectly known Isopoda. Part I.Bihang till Kongl. Svenska vetenskaps-akademiens handlingar 10 (2): 1-32.

Bruce NL. 1986. Revision of the Isopod crustacean genus Mothocya Costa, in Hope, 1851 (Cymothoidae: Flabellifera), parasitic on marine fishes. J Nat Hist 20 (5): 1089-1112. DOI: 10.1080/00222938600770781.

Brusca RC. 1981. A monograph on the Isopoda Cymothoidae (Crustacea) of the eastern Pacific. Zool J Linn Soc 73 (2): 117-199. DOI: 10.1111/j.1096-3642.1981.tb01592.x.

Carausu A. 1959. Contribution à l'étude des Cymothoinae (Isopodes Parasites) de la mer Noire. 2. Un cas d'infestation massive avec Livoneca punctata (Ulj.) chez Caspialosa pontica (Eichw.). Trav. Lucrarile Sesiunii Stiintifice a Statiunii Soologice Marine Agigea 1959: 349-351.

Carus JY. 1885. Prodromus faunae mediterranae sive Descriptio Animalium maris Mediterranei incolarum quam comparata silva rarum quatenus innotuit adiectis locis et nominibus vulgaribus eorumque auctoribus in commodum zoologorum. Schweizerbart, Stuttgart. DOI: 10.5962/bhl.title.11523.

Dollfus RP, Trilles JP. 1976. A propos de la collection R. Ph. Dollfus, mise au point sur les Cymothoadiens jusqu' à présent récoltés sur des Téléostéens du Maroc et de l' Algérie. Bulletin du Muséum National d' Histoire naturelle de Paris 272: 821-830.

Dudich E. 1931. Systematische und biologische Untersuchungen uber die Kalkeinlagerungen des Crustaceenpanzers in polarisiertem lichte. Zoologica Stuttgart 30 (80): 1-54.

Euzet L, Trilles JP. 1961. Sur l'anatomie et la biologie de Cyclocotyla bellones (Otto, 1821) (Monogenea-Polyopisthocotylea). Revue Suisse de Zoologie 68 (2): 182-193. DOI: 10.5962/bhl.part.117723.

Froese R, Pauly D. Editors. 2017. FishBase. World Wide Web electronic publication. www.fishbase.org, version (06/2017).

Gerstaecker A. 1901. Isopoda In: Bronn HG (ed) Die Klassen und Ordnungen der Arthropoden wissenschaftlich dargestellt in Wort und 
Bild.Crustacea (Zweite Hälfte: Malacostraca), Fünfter Band. II., Abtheilung.

Gourret P. 1891. Les Lemodipodes et les Isopodes de Golfe de Marseille. Annales du Musée d'Histoire Naturelle de Marseille 4 (1): 1-44.

Hadfield KA, Horton T, Bruce NL, Schotte M. 2017. Mothocya Costa in Hope, 1851. In: Boyko CB, Bruce NL, Hadfield KA, Merrin KL, Ota Y, Poore GCB, Taiti S, Schotte M, Wilson GDF (eds) (2008 onwards). World Marine, Freshwater, and Terrestrial Isopod Crustaceans database. http://www.marinespecies.org/aphia.php?p=taxdetails\&id=118416.

Heller C. 1866. Carcinologische Beiträge zur Fauna des adriatischen Meeres. Verhandlungen der Zoologisch-botanischen Gessellschaft in Wien 16: 723-760.

Hope FG. 1851. Catalogo dei crostacei Italiani e di molti altri del Mediterraneo. Stabilemento Tipografico di Fr. Azzolino, Napoli. DOI: 10.5962/bhl.title.3924.

Josipa F, Mirela P, Sanja M, Jakov D. 2007. An occurrence of isopode parasitism on black scorpion fish, Scorpaena porcus (Perciformes, Scorpaenidae) in the eastern part of Adriatic Sea. 12th European Congress of Ichthyology (ECI-12) Book of abstracts / Buj, Ivana; Zanella, Linda; Mrakovčić, Milorad (ed).-Zagreb: Tipomat 91.

Kırkım F. 1998. Ege Denizi Isopoda (Crustacea) Faunasının Sistematiği ve Ekolojisi Üzerine Araştırmalar. Doktora Tezi, Ege Üniversitesi, Fen Bilimleri Enstitüsü, İzmir, 233syf. [Turkish]

Kononenko AF. 1988. Parasitic Isopoda of the Black Sea fishes Wiadomosci Parazytologiczne 34 (1), 1p.

Kussakin OG. 1979. Marine and Brackish Water lsopod Crustacea Suborder Flabellifera. Academy of Science, USSR, Leningrad. [Russian]

Markewitsch AP. 1934. Skorupiaki pasorzytnicze ryb. Ukrainy. Die Schmarozerkrebse der Fische der Ukraine. Annales Museum Zoology Polonia 12: 223-249.

Martin MB, Bruce NL, Nowak BF. 2013. Redescription of Ceratothoa carinata (Bianconi, 1869) and Ceratothoa oxyrrhynchaena Koelbel, 1878 (Crustacea: Isopoda: Cymothoidae), buccal-attaching fish parasites new to Australia. Zootaxa 3683 (4): 395-410. DOI: 10.11646/zootaxa.3683.4.4.

Milne-Edwards H. 1840. Histoire Naturelle des Crustacés Comprenent l'anatomie, la physiologie et la classification de ces animaux. Roret, Paris.

Montalenti G. 1941. Studi sull'ermafroditismo dei Cimotoidi. 1. Emetha audouinii (M. Edw.) e Anilocra physoides (L.). Pubblicazioni della Stazione Zoologica di Napoli 18 (3): 337-394.

Montalenti G. 1948. Note sulla sistematica e la biologia di alcuni Cimotoidi del Golfo di Napoli (gen. Emetha, Mothocya, Anilocra, Nerocila). Archivio di Oceanografia e Limnologia, Venezia 5: 25-81.

Muradian Z. 1972. Contribution a La Connaissance de la Parasitofaune des Clupeides (Clupeidae, Pisces) de Roumanie. Travaux du Museum D'Histoire Naturelle Grigore Antipa 12: 11-25.

Nikolaeva VM. 1963. La faune parasite de quelques bancs locaux de poissons de la Mer Noire. Trav Station Biology of Sabastopol (traduction CNRS du texte Russe) 16: 1-46.

Öktener A, Trilles JP, Alas A, Solak K. 2009. New hosts for species belonging to the genera Nerocila, Anilocra, Ceratothoa, Mothocya and Livoneca (Crustacea, Isopoda, Cymothoidae). Bull Eur Assoc Fish Pathol 29 (2): 49-54.

Öktener A, Trilles JP, Koç HT, Erdoğan Z. 2010. Mothocya taurica (Czerniavsky, 1868) female redescription on Alosa fallax from the Black Sea Coasts of Turkey. Egyptian J Aquat Res 36 (4): 623-629.

Öktener A, Trilles JP. 2004. Report on the Cymothoids (Crustacea, Isopoda) collected from marine fishes in Turkey. Acta Adriatiaca 45 (2): $145-154$

Olguner A. 2008. Bazı Deniz Balıklarında Görülen Metazoan Parazitler. Yüksek Lisans Tezi, Sinop Üniversitesi, Sinop, 50syf [Turkish]

Papapanagiotou EP, Trilles JP, Photis G. 1999. First record of Emetha audouini, a cymothoid isopod parasite, from cultured sea bass Dicentrarchus labrax in Greece. Dis Aquat Org 38 (3): 235-237. DOI: $10.3354 /$ dao0038235.

Papoutsoglou SE. 1976. Metazoan parasites of fishes from Saronicos Gulf, Athens, Greece. Thalassographica, Institute of Oceanography Fishery Research Greece 1 (1): 69-91.

Poore GCB, Bruce NL.2012. Global diversity of marine Isopods (Except Asellota and Crustacean Symbionts). PLoS One 7: 1-15. DOI: 10.1371/annotation/3260cd00-89cf-4e08-ab25-07e0be598ab4
Popov AM. 1933. Über parasitische Isopoden von Fischen aus dem Schwarzen Meer. Zoologischer Anzeiger Akademische Verlagsgesellschaft, MBH Leipzig 101: 193-198.

Quignard JP, Zaouali J. 1980. Les lagunes pé-riméditerranéennes. Bibliographie ichtyologique annotée. Premiere partie: les étangs français de Canet à Thau. Bulletin de l'Office National des Pêches de Tunisie 4: 293-360.

Quintard-Dorques B. 1966. Contribution à l'étude des poissons de la famille des Centracanthidae, Genra Spicara de la région de Sète. Annales de l'Université et de l'Association Régionale pour l'étude et al Recherche Scientifiques 4: 79-88.

Radujkovic BM, Romestand B, Trilles JP. 1984. Les isopodes parasites de la faune yougoslave. I. Cymothoidae parasites de poissons marins de la région de l'Adriatique Méridionale. Acta Adriatica 25: 161-181.

Radujković BM. 1982. Isopoda-parasites of the south Adriatic economically important fish species. Acta Adriatica 23 (1/2): 153161.

Ramdane R, Bensouilah MA, Trilles JP. 2006. Comparison entre les Cymothoidae (Crustacea, Isopoda) recoltes sur les poissons teleosteens des cotes Tunisiennes et Algeriennes. Bull l'INSTM N (spécial 11: Actes des 8èmes Journées des Sciences de la Mer): 29-33.

Ramdane Z, Bensouilah MA, Trilles JP. 2009. Étude comparative des crustacés isopodes et copépodes ectoparasites de poissons marins algériens et marocains. Cybium 33 (2): 123-131.

Rathke H. 1837. Zur fauna der Krym. Memoires des Savaus Etrangers III: 291-454.

Romestand B, Trilles JP. 1977. Influence des Cymothoadiens (Crustacea, Isopoda, Flabellifera) sur certaines constantes hématologiques des poissons hôtes. Zeitschrift für Parasitenkunde 52 (1): 91-95. DOI: 10.1007/BF00380562

Romestand B, Voss-Foucart MF, Jeuniaux Ch, Trillès JP. 1976. Les Acides AminésLibres Du Sérum Des Cimothoidae (Crustacés, Isopodes, Parasites De Poissons) Et De Quelques Téléostéens'. Arch $\begin{array}{llll}\text { Physiol } & \text { Biochem } 84 & \text { (5): } & \text { 981-988. }\end{array}$ $10.3109 / 13813457609069459$.

Sartor SM. 1986. Incidencia de isopodos parasitas (Cymothoidae) em peixes da plataforma continental Brasileira. Bolletin Institute Oceanography Saint Paulo 34: 1-12. DOI: 10.1590/S037355241986000100001

Sartor SM. 1987. Desenvolvimento marsupial e ciclo de vida de Cymothoa liannae Srtor et Pires (Isopoda, Cymothoidae), parasita de peixes. Bolletin Institute Oceanography Saint Paulo 35 (1): 43-51. DOI: 10.1590/S0373-55241987000100006.

Schioedte JC, Meinert F. 1883. Symbolae and monographium Cymothoarum crustaceorum familiae. III. Saophridae. IV.Ceratothoinae. Naturhistorisk Tidsskrift, Kjobenhavn 13: 281-378.

Schotte M. 2007. Emetha Schioedte \& Meinert, 1883. In: Boyko CB, Bruce NL, Hadfield KA, Merrin KL, Ota Y, Poore GCB, Taiti S, Schotte M, Wilson GDF (eds) (2008 onwards). World Marine, Freshwater, and Terrestrial Isopod Crustaceans database. http://marinespecies.org/aphia.php/aphia.php?p=taxdetails\&id=11841 1.

Schotte M. 2008a. Mothocya taurica (Czerniavsky, 1868). In: Boyko CB, Bruce NL, Hadfield KA, Merrin KL, Ota Y, Poore GCB, Taiti S, Schotte M, Wilson GDF (eds) (2008 onwards). World Marine, Freshwater, and Terrestrial Isopod Crustaceans database. http://www.marinespecies.org/aphia.php?p=taxdetails\&id=118904

Schotte M. 2008b. Emetha audouini (H. Milne Edwards, 1840). In: Boyko CB, Bruce NL, Hadfield KA, Merrin KL, Ota Y, Poore GCB, Taiti S, Schotte M, Wilson GDF (eds) (2008 onwards). World Marine, Freshwater, and Terrestrial Isopod Crustaceans database. http://www.marinespecies.org/traits/aphia.php?p=taxdetails\&id=1188 94

Stalio L. 1877. Catalogo metodico e descrittivo dei Crostacei podottalmi ed Edriottalmi dell' Adriatico. Atti de Reale Instituto Veneto di Scienze, Lettre ed Arti 3: 1-274. DOI: 10.5962/bhl.title.10387.

Stossich M. 1880. Prospetto della fauna de mare Adriatico. Parte III. Bollettino della Societa Adriatica di Scienze Naturale in Trieste 6: 195.

Thampy DM, John PA. 1974. Sex-reversal and androgenic gland in the fish parasite Irona far (Cymothoidae: Isopoda: Crustacea). Intl Parasitol 4 (6): 575-583. DOI: 10.1016/0020-7519(74)90021-6.

Trilles JP, Radujkovic BM, Romestand B. 1989. Parasites des Poissons Marins du Montenegro: Isopodes. Acta Adriatica 30 (1/2): 279-306. 
Trilles JP. 1962. Remarques morphologiques et biologiques sur les 'Isopodes Cymothoida, parasites des poissons, de l'Etang de Thau. Naturalia Monspelogia 3: 101-124.

Trilles JP. 1964. Specificite parasitaire chez les isopodes Cymothoidae Mediterraneens. Note preliminaire. Vie et Milieu 15: 105-116.

Trilles JP. 1968. Recherches sur les Isopodes. Cymothoidae de cotes Françaises. I. Systematique et faunistique. II. Bionomie et parasitism. [These de Doctorat sciences], CNRS, AO 2305, Montpellier, France.

Trilles JP. 1972a. Les Cymothoidae (Isopoda, Flabellifera) des côtes françaises (systématique, faunistique, écologie et répartition géographique). I. Les Ceratothoinae Schiodte and Meinert, 1883. Bulletin du Muséum national d'Histoire naturelle, Paris, 3e série, Zoologie 91: 1191-1230.

Trilles JP. 1972b. Les Cymothoidae (Isopoda, Flabellifera) du Muséum National d'Histoire Naturelle de Paris. Etude critique accompagnée de précisions en particulier sur la répartition géographique et l'écologie des différentes espèces représentées. I. Les Ceratothoinae Schioedte et Meinert, 1883. Bulletin du Muséum d'Histoire Naturelle, Paris, 3e série, Zoologie 91: 1231-1268. [French]

Trilles JP. 1972c. Sur la structure des plkopodes et des oosttgites chez les Cymothoidae (Isopoda, Flabellifera) et ses rapports avec les caractbistiques kologiques des espPces. Bulletin du Muséum National d'Histoire Naturelle, Paris, 3ème série 91 (3): 1269-1277.
Trilles JP. 1976. Les Cymothoidae (Isopoda, Flabellifera) des collections du Museum National d'Histoire Naturelle de Paris. IV. Les Lironecinae Schioedte et Meinert, 1884. Bulletin du Museum National d'Histoire NaturelIe, Paris, 3 serie 390 (272): 773-800.

Trilles JP. 1977. Les Cymothoidae (Isopoda, Flabellifera; parasites de poissons) du Rijksmuseum van Natuurlijke Historie de Leiden. Méditerranée et Atlantique nord-oriental. Zoologische Mededelingen (Leiden) 52: 7-17.

Trilles JP. 1994. Les Cymothoidae (Crustacea, Isopoda) du Monde (Prodrome pour une Faune). Studa Marina 21/22: 1-288.

Uljanin VN. 1871. Beitrage zur fauna des Schwarzen Meeres. Protok. Sitzungsber Naturf. Antrop. Und Ethnogr. Gesellsch. Moscou, 113114.

Uljanin VN. 1872. Data on the fauna of the Black Sea. lzvestiya Moskovskogo Obshchestva Lyubitelei Estestvoznaniya, Antropoligii i Etnografii 9: 79132.

Vasiliu G, Carausu MA. 1948. Contribution A l'etude des Cymothoinae (Isopodes parasites) de la Mer Noire. Annales Scientifiques de 1' Université de Jassy 31: 175-188.

Wägele JW. 1987. Evolution und phylogenetisches System der Isopoda: Stand der Forschung und neue Erkenntnisse. Universität Oldenburg.

WoRMS Editorial Board. 2017. World Register of Marine Species. Available from http://www.marinespecies.org at VLIZ. DOI: $10.14284 / 170$. 